\title{
Long-Term Water Footprint Assessment in a Rainfed Olive Tree Grove in the Umbria Region, Italy
}

\author{
Luca Rossi ${ }^{1,+}$, Luca Regni ${ }^{1, *,+}$, Sara Rinaldi ${ }^{2}$, Paolo Sdringola ${ }^{3}$, Roberto Calisti ${ }^{1}$, \\ Antonio Brunori ${ }^{1}$, Francesca Dini ${ }^{1}$ and Primo Proietti ${ }^{1}$ \\ 1 Department of Agricultural, Food and Environmental Sciences, University of Perugia, via Borgo XX Giugno, \\ 74, 06121 Perugia, Italy; luca.rossi2092@gmail.com (L.R.); saacr@libero.it (R.C.); \\ antonio.brunori65@gmail.com (A.B.); francesca.dini@gmail.com (F.D.); primo.proietti@unipg.it (P.P.) \\ 2 Department of Engineering, University of Perugia, via G. Duranti 67, 06121 Perugia, Italy; \\ rinaldi.sara@yahoo.it \\ 3 ENEA Italian National Agency for New Technologies, Energy and Sustainable Economic \\ Development-Casaccia Research Centre, via Anguillarese 301, 00123 S. Maria di Galeria, Rome, Italy; \\ paolo.sdringola@enea.it \\ * Correspondence: regni.luca.agr@gmail.com \\ + These authors contributed equally to the work.
}

Received: 4 December 2019; Accepted: 23 December 2019; Published: 28 December 2019

\begin{abstract}
Life Cycle Assessment (the systematic analysis of the environmental impact of products during their entire life cycle), Carbon Footprint and Water Footprint assessments play an important role in decision-making processes. These assessments can help guide land management decisions and will likely play a larger role in the future, especially in natural areas with high biodiversity. Agriculture is a substantial consumer of fresh water, so it is important to identify causes and possible solutions to optimize agricultural water use. Water footprint assessments consider water consumption from several points of view and aid in reaching Sustainable Development Goals. Olive trees are a widespread agricultural crop growing in the Mediterranean Basin and are particularly important in the Umbria region in Italy. This paper estimates the water footprint impact related to the production of $1 \mathrm{~kg}$ of olives in a rainfed olive orchard managed using low environmental impact techniques. Eleven years of data collection (meteorological data, olives yield data, processes data) are analyzed for typical rural conditions. The results show that local management techniques have lower water requirements than standard international usages. These results can be used to improve and to further explore agricultural water use.
\end{abstract}

Keywords: olive trees; water footprint assessment; freshwater consumption; sustainability

\section{Introduction}

According to the Inter-governmental Panel on Climate Change [1], human processes are warming the atmosphere and oceans, creating variations in global water cycles, reducing snow and ice cover, increasing sea level and producing other climatic changes. To sustain landscapes in a changing climate, studies regarding goods and services production and consumption processes are needed. Particularly, Water Footprints (WF) - the amount of water needed to obtain a good or a service [2], need to be understood to optimize water use.

The United Nations General Assembly adopted the Sustainable Development Goals (SDGs) for the period 2015-2030. These SDGs explicitly target water quality improvement, water-use efficiency increases and water scarcity reductions worldwide. In particular, Goal 6 is fully devoted to water and aims to substantially increase water-use efficiency across all sectors by 2030 . This goal will help 
ensure sustainable ready supplies of freshwater to reduce the number of people suffering from water scarcity [3].

Among human activities, agriculture represents $92 \%$ of the freshwater footprint [4]. One third of this activity supports farming of livestock. Several factors of WF are involved in the livestock industry: (a) type of production system, (b) composition, origin and conversion efficiency of the feed and (c) water related to drinking and other on-farm activities [4]. Livestock, particularly red meat, has a very high WF value of 15,400 L of water per $\mathrm{kg}$ of final product [5].

The WF concept is strictly related to the virtual water concept, with the aim of creating a consumption-based indicator of freshwater use. WF is an ecological footprint indicator, accounting for the appropriation of natural capital, both for the direct and the indirect water use from the consumption and production of good and services. WF can be calculated for a process, a product, a consumer/group of consumers and a producer. The total amount of water involved in a WF assessment can be divided in three components: green, blue and grey water. The green water is the rainwater used to grow crops. The blue water is fresh surface and groundwater. The grey water is the water necessary to return the concentration of the pollutants in the groundwater to the natural balance [6].

For vineyards near Palermo, in Sicily region (Italy) WF value for wine production was 700 liters of water use per liter of wine [7]. This WF assessment involved assessing the vineyard (evapotranspiration, irrigation, fertilization, pesticide application) and the winery (washing and cleaning, wine-making, staff water use, bottling and packaging). The green WF was the largest component of the total WF. Other studies in Italy and in Europe on other fruit tree species, particularly olive trees, found similar results.

Olive oil represents about $4 \%$ of the global vegetable oil consumption. It accounts for $50-60 \%$ of consumption in traditional olive oil producing countries and $0.8-7 \%$ in other countries. Extra virgin oil is acknowledged as a very important product, especially in the Mediterranean region, for its healthy, traditional and environmental values. Olive tree grove represent a large part of the world's agriculture surface at 10,804,517 ha in 2017 [8]. The Water Footprint Network identifies a fairly high WF value of $3015 \mathrm{~L}$ of water per $\mathrm{kg}$ of olives.

The WF of the most common olive growing systems have been compared by different authors [9-12]. Analysis of three different olive-growing systems (traditional, intensive and high-density) in Apulia region (Italy) reveal that the least water demanding system that maintained a high yield $\left(9 \mathrm{t} \mathrm{ha}^{-1}\right)$ was the high density system (irrigation volume $=1660 \mathrm{~m}^{3} \mathrm{ha}^{-1} \mathrm{year}^{-1}$ and ammonium nitrate requirements $=320 \mathrm{~kg} \mathrm{ha}^{-1}$ ) [9]. In Basilicata, South Italy, a study of the table olive cultivar (Maiatica di Ferrandina) revealed that cover crops were more important than tilled soil in storing the water from rainfall [10].

A WF assessment in the Alentejo region of South Portugal, which requires frequent summer irrigation, reveals that olive yield was significantly higher in hedgerow orchards compared with intensively managed olive groves [11,12]. In both cases, irrigation was adequate to produce high quality extra virgin olive oil [11]. A WF assessment of Protected Designation of Origin (PDO) areas (area where a product must be traditionally and entirely manufactured) in the Umbria region, reveal that, to be more sustainable, the production olive oil has to reduce blue and grey water use. The olive oil production varied based on type of water: Green water $=257-3000 \mathrm{~m}^{3}$ of water ton ${ }^{-1}$ (average value 1418); Blue water $=150-1852 \mathrm{~m}^{3}$ ton $^{-1}$ (average value 1245 ); Grey water $=1400-1600 \mathrm{~m}^{3}$ ton $^{-1}$. The Grey water calculations only considered ammonia nitrogen and assumed its natural presence was negligible [13].

Our study is the first study to assess a long-term (2007-2017) WF for assessment olive groves that considers the three components of WF. This study uses measured data, not data derived from the literature, to calculate WF metric from olive groves located between Assisi and Spoleto, Italy, which is an FAO Globally Important Agricultural Heritage System (GIAHS). In this region, small and medium-sized farms are important with a traditional cultivation the most common practice. In this region. Increasing energy efficiency, reducing potential environmental effects and maximizing olive production and quality is paramount to sustaining both agricultural productivity and environmental 
sustainability [14]. This paper aims to estimate the WF related to the production of $1 \mathrm{~kg}$ of olives over a long time period in a rainfed olive orchard managed through low environmental impact techniques.

\section{Materials and Methods}

\subsection{Study Area, Biomass and Yield Values}

The study was carried out in a rainfed olive grove situated in Central Italy (Sterpeto, Assisi municipality-Perugia, Umbria region, $12^{\circ} 56^{\prime}$ E longitude, $43^{\circ} 11^{\prime} \mathrm{N}$ latitude and about $400 \mathrm{~m}$ a.s.l.). The olive grove was planted in year 2000. The trees (cv Leccino) are trained to the vase system with a planting spacing of $5.5 \times 5.5 \mathrm{~m}$ (about 330 trees per ha). The Leccino cultivar is vigorous with high, constant olive production. It is widespread in central Italy and it is found in most olive-growing areas in Italy as well as worldwide (Australia, Chile, USA - California, etc.).

The soil in the study is characterized by an alkaline $\mathrm{pH}(8.1)$, a loam texture (sand $41 \%$, silt $34 \%$, clay $25 \%$ ) with low organic matter, total $\mathrm{N}$, available $\mathrm{P}$ and exchangeable K. Soil analyses were carried out by Environmental and Agricultural Science Department of University of Studies of Perugia in 2014.

The study area has a continental climate. The average temperature difference between the coldest month (January) and the hottest month (July) is $19-20^{\circ} \mathrm{C}$ (with an average diurnal thermal range of $10-11^{\circ} \mathrm{C}$ and an average annual air temperature of $13-14^{\circ} \mathrm{C}$ ). Extreme temperatures were recorded in the range $-7^{\circ} \mathrm{C}$ up to $36^{\circ} \mathrm{C}$. The annual average precipitation is $800-820 \mathrm{~mm}$, mostly concentrated in the autumn, winter and spring. In summer, precipitation is scarce with prolonged and frequent droughts that can negatively affect tree productivity.

All tree parameters (including amounts of pruning materials and olives per tree) were measured annually and in a direct way on 32 trees in eight randomized blocks [15]. The study accounts for all the processes associated with the cultivation of olives (Table 1): fertilization, phytosanitary treatments, soil management, pruning, pruning material management and harvesting.

For the eleven-year life cycle of the olive grove, data were collected through farmer questionnaires related to material and energy flows for 1 ha of olive grove:

- $\quad$ Fertilization phase: the amount of fertilizer used, the fuel consumption by agricultural machinery and the working-hours needed.

- Pruning: the transport, the fuel consumption by agricultural machinery and the man-hours needed.

- Pruning material management: the fuel consumption by agricultural machinery and the working-hours needed.

- $\quad$ Phytosanitary treatments: the amount of pesticide used, the fuel consumption by agricultural machinery and the working-hours needed.

- $\quad$ Soil management: (green cover mowing): the fuel consumption by the agricultural machinery and the working-hours needed.

- Chipping of pruning material: the fuel consumption by agricultural machinery and the man-hours needed.

- Olive harvesting: the fuel consumption by agricultural machinery, transport and the working-hours needed.

In the same study area, a Life Cycle Assessment and Carbon Footprint assessments were performed in 2014 [15].

\subsection{WF Methodology}

All the three components of the WF (green, blue, grey water) were examined to estimate the total WF value [6]. The total WF was calculated as follows:

$$
\left.W F_{\text {proc }}=W F_{\text {proc,green }}+W F_{\text {proc, blue }}+W F_{\text {proc,grey }} \text { (volume } / \text { mass }\right) .
$$


Climatic data of rainfall, minimum and maximum temperatures, relative humidity, wind speed and solar radiation were collected daily between 2007 to 2017 (Supplementary Table S1). The rainfall and temperature were obtained from the Regional Hydrographic Service from the close weather station of Pianello ( $12^{\circ} 54^{\prime}$ E longitude, $43^{\circ} 14^{\prime} \mathrm{N}$ latitude). The wind speed data were obtained from the Regional Hydrographic Service from the close weather station of Assisi $\left(12^{\circ} 60^{\prime}\right.$ E longitude, $43^{\circ} 07^{\prime} \mathrm{N}$ latitude). The relative humidity data were obtained from "Archivio Meteo Assisi" (http://archivio-meteo.distile. it/tabelledati-archivio-meteo/) from the weather station of Assisi $\left(12^{\circ} 60^{\prime}\right.$ E longitude, $43^{\circ} 07^{\prime} \mathrm{N}$ latitude). The solar radiation and hours of sunshine data were obtained from Astronomical Applications Dept. U.S. Naval Observatory Washington, DC 20392-5420, (http://aa.usno.navy.mil/data/docs/Dur_OneYear.php) as calculated for the study area.

Some weather data are not directly on site but obtained from the nearest weather stations (from $3.5 \mathrm{~km}$ and $7 \mathrm{~km}$ away). Water Footprint assessment results are expressed in $\mathrm{m}^{3}$ of water per ton of olives.

Table 1. Processes considered in Water Footprint (WF) assessment.

\begin{tabular}{|c|c|c|c|c|c|}
\hline Process & $\begin{array}{l}\text { Working } \\
\text { Hours }\end{array}$ & $\underset{\text { (L) }}{\text { Agricultural Fuel Oil }}$ & Material & Transportation & Year \\
\hline Fertilization & 3 & 15 (tractor) & $\begin{array}{c}\text { Urea } 330 \mathrm{~kg} \mathrm{ha}^{-1}(\mathrm{~N} \\
\text { title } 46 \%)\end{array}$ & - & Every year \\
\hline Pruning & $\begin{array}{l}20 \text { ( } 10 \text { for the } \\
\text { first two years) }\end{array}$ & $\begin{array}{l}20 \text { (tractor) (10 for the } \\
\text { first two years) }\end{array}$ & 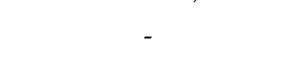 & $100 \mathrm{~km}$ & Every year \\
\hline Harvesting & $\begin{array}{l}30 \text { (15 for the } \\
\text { first two years) }\end{array}$ & $\begin{array}{l}40 \text { (tractor) ( } 20 \text { for the } \\
\text { first two years) }\end{array}$ & - & $100 \mathrm{~km}$ & Every year \\
\hline $\begin{array}{c}\text { Phytosanitary } \\
\text { treatments }\end{array}$ & 年 & 20 (tractor) & $\begin{array}{l}\text { Copper Sulphate: } 1 \mathrm{~kg} \\
\text { per } 100 \mathrm{~L} \text { of water }(3 \mathrm{~kg})\end{array}$ & - & Every year \\
\hline Green cover mowing & 3 & 30 (tractor) & - & - & Every year \\
\hline Chipping of prunings & 4 & 26 (tractor) & - & - & Every year \\
\hline
\end{tabular}

\subsubsection{Green Water}

Green water refers to the precipitation that is stored in or stays on top of the soil or vegetation [6]. It includes water lost through evapotranspiration and water incorporated in plant biomass but does not include precipitation that is run off or that goes groundwater recharge. Most of agricultural production worldwide is based on green water consumption [16]. The WF for green water is calculated as:

WFproc,green $=$ GreenWaterEvaporation + GreenWaterIncorporation (volume/time).

The Green WF of the agricultural process was calculated with CROPWAT 8.0, software released by Food and Agriculture Organization (FAO) that relies on biomass, soil and meteorological data. Climatic data are input on a monthly basis. Soil parameters include total available soil moisture (Field capacity-Wilting point $\left.\left(\mathrm{mm} \mathrm{m}^{-1}\right)\right)$, maximum rain infiltration rate $\left(\mathrm{mm} \mathrm{day}^{-1}\right)$, maximum rooting depth $(\mathrm{cm})$, initial soil moisture depletion (as \% Total Available Moisture), initial available soil moisture $\left(\mathrm{mm} \mathrm{m}^{-1}\right)$. The soil type of "Medium" was used as the study area has alkaline, loam/clay-loam soils with no stony components.

Crop parameters include single crop coefficients $(\mathrm{Kc})$ for each stages (initial, development, mid-season, late season) length (days), rooting depth (m), critical depletion (fraction), yield response factor and crop height $(\mathrm{m})$. The input values were obtained from the CROPWAT manual. For the initial stage, the used Kc value was 0.65 , for development, mid-season and late season stages, the Kc was 0.70 , as per the CROPWAT manual.

Based on previous methods [9], the evapotranspiration factor $\left(E T_{\text {green }}\right)$ was calculated as the minimum between Crop Water Requirement (CWR) and rainfall $\left(\mathrm{P}_{\text {eff }}\right)$, which was $537.6 \mathrm{~mm}$ in 2007. 
The green component in CWU $\left(\mathrm{m}^{3} \mathrm{ha}^{-1}\right)$ is calculated by accumulation of daily evapotranspiration $\left(E T_{\text {green }}, \mathrm{mm} \mathrm{day}^{-1}\right)$ over the complete growing period according to the following equation:

$$
C W U_{\text {green }}=10 \times \sum_{d=1}^{\text {lgp }} E T_{\text {green }}\left(\mathrm{m}^{3} \mathrm{ha}^{-1}\right)
$$

where $E T_{\text {green }}$ represents green water evapotranspiration, the factor 10 is meant to convert water depths in mm into water volumes per land surface in $\mathrm{m}^{3} \mathrm{ha}^{-1}$ and lgp is the period length in days. For the $C W U_{\text {green }}$ a value of $5376.0 \mathrm{~m}^{3} \mathrm{ha}^{-1}$ was obtained. $W f_{\text {green }}$ was calculated as $C W U_{\text {green }}$ divided by the olive yield $(\mathrm{Y})$ in $\mathrm{t} \mathrm{ha}^{-1}$.

\subsubsection{Blue Water}

The blue water refers to the fresh surface or groundwater that either (a) evaporates, (b) is incorporated into the product, (c) does not return to the same catchment area, for example, it is returned to another catchment area or the sea and (d) does not return in the same period, for example, it is withdrawn in a scarce period and returned in a wet period [6]. The WF for blue water is calculated as:

$$
\text { WFproc,blue }=\text { BlueWaterEvaporation }+ \text { BlueWaterIncorporation }+ \text { LostReturnflow }\left(\mathrm{m}^{3} \mathrm{t}^{-1}\right) .
$$

The blue Water Footprint component $\left(W F_{\text {blue }}\right)$ was obtained dividing the $C W U_{\text {blue }}$ by olive yield amount $(\mathrm{Y})$. The value of $C W U_{\text {blue }}$ from $E T_{\text {blue }}$ using the equation:

$$
C W U_{\text {blue }}=10 \times \sum_{d=1}^{\text {lgp }} E T_{\text {blue }}\left(\mathrm{m}^{3} \mathrm{ha}^{-1}\right),
$$

where $E T_{\text {blue }}$ was estimated from IR (irrigation requirement) as the minimum between IR and $\mathrm{I}_{\text {eff }}$ (irrigation efficiency). IR was calculated as the difference between crop water requirement and effective precipitation. The crop water requirement is the total water needed for evapotranspiration for a given crop in a specific climate regime when adequate soil water is maintained by rainfall and/or irrigation, such that it does not limit plant growth and crop yield. The effective precipitation is the portion of the total precipitation that is retained by the soil, so that it is available for crop production. $\mathrm{I}_{\text {eff }}$ is the ratio of the amount of water consumed by the crop to the amount of water supplied through irrigation.

The water irrigation was equal to zero, so that only the water involved in the treatments has been considered, which allows the direct and the indirect fractions of the Blue Water Footprint to be estimated. The direct fraction is linked to the water used directly in the field; the indirect fraction is the fraction of water involved for the production of products used in agronomical practices (i.e., diesel fuel, urea and copper sulphate).

\subsubsection{Grey Water}

The Grey Water Footprint is defined as the volume of freshwater that is required to assimilate the load of pollutants based on natural background concentrations and existing ambient water quality standards [6]. A three-tier approach is recommended to estimate diffuse pollution loads, similar to the ones used by the Intergovernmental Panel on Climate Change (IPCC) to estimate greenhouse gas emissions [17]. From Tier 1 to Tier 3, even if the accuracy increases, feasibility decreases. Thus, we used a Tier 1 approach. This approach uses a fixed fraction to translate data on the amount of chemicals applied to the soil to an estimate of the amount of chemicals that enter the groundwater or surface water system. The fraction has to derive from existing literature and may depend on the considered chemical. This Tier 1 estimate will suffice as a first rough estimate but obviously excludes relevant factors such as soil type, agricultural practice, soil hydrology and interaction between different chemicals in the soil [6].

The grey component in the water footprint of growing a crop or tree $\left(W F_{\text {proc,grey, }} \mathrm{m}^{3} \mathrm{t}^{-1}\right)$ is calculated as the chemical application rate to a field per hectare $\left(A R, \mathrm{~kg} \mathrm{ha}^{-1}\right)$ times the leaching 
run-off fraction $(\alpha)$ divided by the maximum acceptable concentration $\left(c_{\max }, \mathrm{kg} \mathrm{m}^{-3}\right)$ minus the natural concentration for the considered pollutant $\left(c_{\max }, \mathrm{kg} \mathrm{m}^{-3}\right)$ and then divided by Yield $\left(Y, \mathrm{tha}^{-1}\right)$ :

$$
W F_{\text {proc,grey }}=\left((\alpha \times A R) /\left(c_{\text {max }}-c_{\text {nat }}\right)\right) / Y\left(\mathrm{~m}^{3} \mathrm{t}^{-1}\right) .
$$

The dimensionless factor $\alpha$ stands for the leaching-run-off fraction, defined is the fraction of applied chemicals reaching freshwater bodies. This equation is the simplest, least detailed method to estimate the grey water footprint in the case of diffuse pollution [6]. The $\alpha$ quantification was estimated based on an average standard value obtained from the manual "Grey water footprint accounting: Tier 1 supporting guidelines" [18]. The natural concentration in receiving water body, $c_{\text {nat }}$, is generally assumed to be 0 . The threshold values for the quantification of the $c_{\max }$ allowed are established by the Legislative Decree 3 April 2006, no. 152 about Environmental regulations [19].

\section{Results}

Results of Total WF and of every WF component are reported in Table 2 and Figure 1.

Table 2. Olive production, green, blue and grey WF 2007-2017 as $\mathrm{m}^{3}$ of water per $\mathrm{kg}$ of olives ${ }^{-1}$.

\begin{tabular}{|c|c|c|c|c|c|}
\hline & $\begin{array}{l}\text { Production } \\
\left(\mathrm{kg} \mathrm{ha}^{-1}\right)\end{array}$ & $\begin{array}{c}\text { Green Water } \\
\text { Footprint }\left(\mathrm{m}^{3} \mathrm{~kg}^{-1}\right)\end{array}$ & $\begin{array}{c}\text { Blue Water } \\
\text { Footprint }\left(\mathrm{m}^{3} \mathrm{~kg}^{-1}\right)\end{array}$ & $\begin{array}{c}\text { Grey Water } \\
\text { Footprint }\left(\mathrm{m}^{3} \mathrm{~kg}^{-1}\right)\end{array}$ & $\begin{array}{c}\text { Total Water } \\
\text { Footprint }\left(\mathrm{m}^{3} \mathrm{~kg}^{-1}\right)\end{array}$ \\
\hline 2007 & 4455 & 1.20 & 0.002 & 0.22 & 1.42 \\
\hline 2008 & 5847 & 1.14 & 0.001 & 0.17 & 1.31 \\
\hline 2009 & 6131 & 0.94 & 0.001 & 0.16 & 1.10 \\
\hline 2010 & 6494 & 1.00 & 0.001 & 0.15 & 1.15 \\
\hline 2011 & 5068 & 1.07 & 0.001 & 0.20 & 1.27 \\
\hline 2012 & 4468 & 1.36 & 0.002 & 0.22 & 1.58 \\
\hline 2013 & 9220 & 0.68 & 0.001 & 0.11 & 0.79 \\
\hline 2014 & 4837 & 1.42 & 0.002 & 0.21 & 1.63 \\
\hline 2015 & 11,606 & 0.49 & 0.000 & 0.08 & 0.57 \\
\hline 2016 & 5445 & 1.31 & 0.001 & 0.18 & 1.49 \\
\hline 2017 & 9372 & 0.65 & 0.001 & 0.10 & 0.75 \\
\hline
\end{tabular}

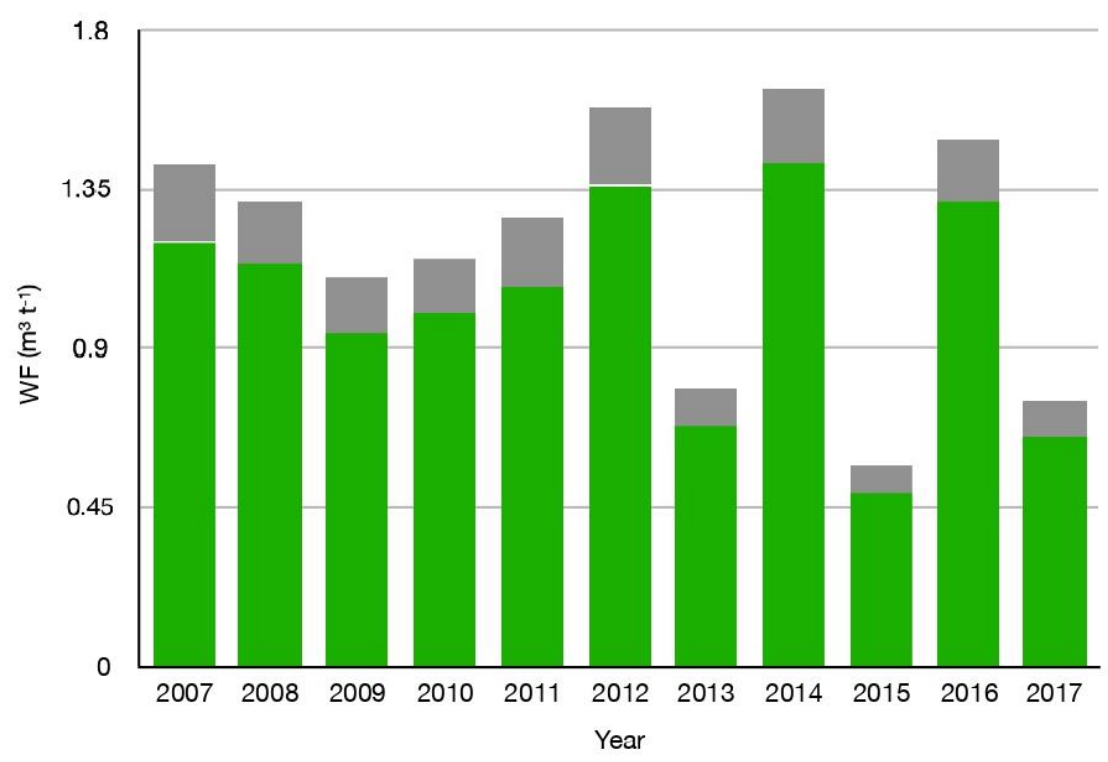

Figure 1. Cont. 


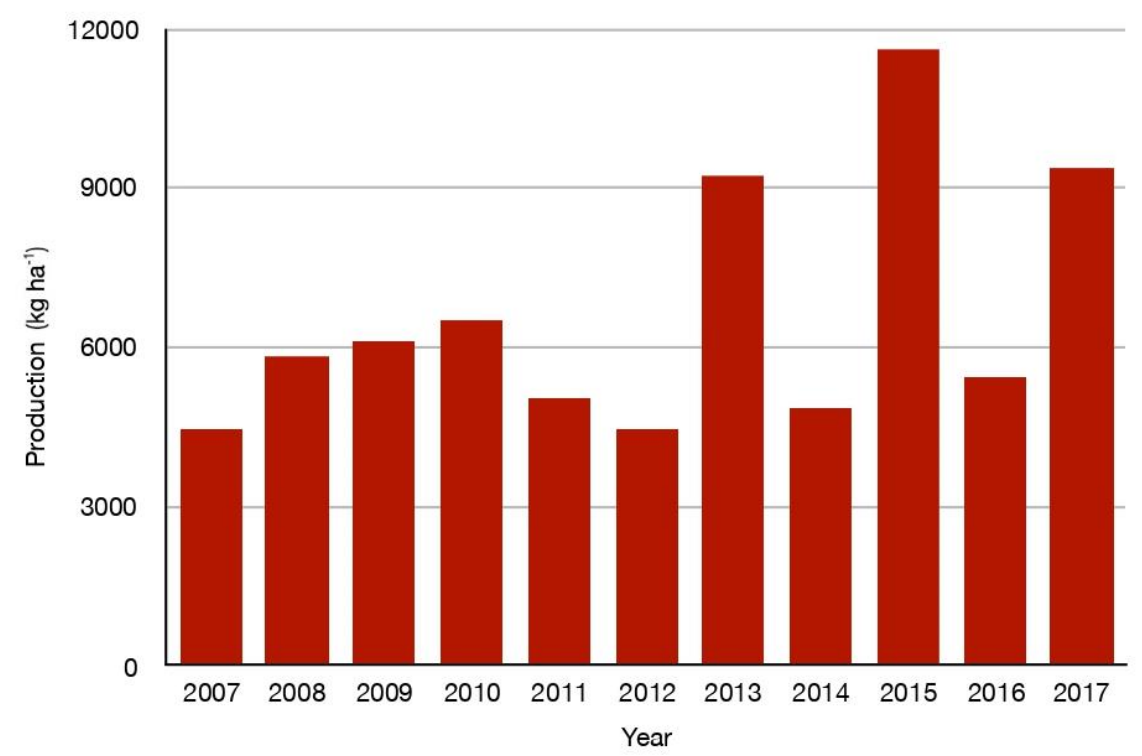

Figure 1. Yearly Green, Blue, Grey and total Water Footprint $\left(\mathrm{m}^{3} \mathrm{t}^{-1}\right)$ compared with olives yearly production $\left(\mathrm{kg} \mathrm{ha}^{-1}\right)$.

\subsection{Green Water}

The maximum value for the Green water was $1.42 \mathrm{~m}^{3} \mathrm{~kg}^{-1}$ (year 2014) while the lowest value was equal to $0.49 \mathrm{~m}^{3} \mathrm{~kg}^{-1}$ (year 2015). The difference is due to a higher olives production in 2015 that was about 2.5 times than in 2014. The lower production in 2014 was due to a massive attack of olive fly. Moreover, 2014 has higher minimum temperature in January and February compared to the average of the considered period.

\subsection{Blue Water}

\subsubsection{Direct Fraction}

For the direct fraction of the Blue water, the only provision is given by the sanitary treatments. In fact, the regime is not irrigated and the only water involved with the contributions is the one given to dilute the copper sulphate. The total amount per hectare was $0.3 \mathrm{~m}^{3} \mathrm{ha}^{-1}$.

\subsubsection{Indirect Fraction}

The values, calculated in $\mathrm{m}^{3}$ of water per $\mathrm{kg}$ of product, have been obtained from the software SimaPro 7.1, produced by Pré Consultants, using the general library Ecoinvent 3 databases.

Applying these values to the three products used and multiplying them for the liters involved per hectare, it is possible to extrapolate the entire weight of the indirect fraction on the Blue Water Footprint and then on the final value of Water Footprint.

Diesel fuel was estimated at $0.0134 \mathrm{~m}^{3} \mathrm{~kg}^{-1}$. The total amount of fuel involved in the agronomical practices was $121 \mathrm{~L} \mathrm{ha}^{-1}$ for the first 2 years. For all the other years the amount was $151 \mathrm{~L} \mathrm{ha}^{-1}$.

Considering a diesel fuel density of $0.835 \mathrm{~kg} \mathrm{~L}^{-1}, 121 \mathrm{~L}$ correspond to $101.03 \mathrm{~kg}$ of diesel, which converts to a water consumption of $1.35 \mathrm{~m}^{3} \mathrm{ha}^{-1}$ year $^{-1}$ for the first two years (2007 and 2008). For 2009-2017, the water consumption was $1.68 \mathrm{~m}^{3} \mathrm{ha}^{-1} \mathrm{year}^{-1}$ (151 L per year and $126.08 \mathrm{~kg}$ of diesel).

The water consumption value for urea was $0.023 \mathrm{~m}^{3} \mathrm{~kg}^{-1}$. As the urea fertilization rate was 330 $\mathrm{kg} \mathrm{ha}^{-1}$ year $^{-1}$, the total water consumption rate was $7.74 \mathrm{~m}^{3} \mathrm{ha}^{-1}$ year $^{-1}$. The water consumption value for copper sulphate is $0.1071 \mathrm{~m}^{3} \mathrm{~kg}^{-1}$. As the copper sulphate fertilization rate was $3 \mathrm{~kg} \mathrm{ha}^{-1}$ year $^{-1}$, the total water consumption rate was $0.32 \mathrm{~m}^{3} \mathrm{ha}^{-1}$ year ${ }^{-1}$. 


\subsection{Grey water}

The $\alpha$ value for urea is 0.1 and the maximum acceptable concentration value for total nitrogen is $15 \mathrm{mg} \mathrm{L}^{-1}$, that means $0.015 \mathrm{~kg} \mathrm{~m}^{-3}$. The calculation for urea, following the formula 5 , is therefore:

$$
\text { WF proc,grey }((0.1 \times 330 \times 0.46) /(0.015)) / \text { annual production }
$$

The $\alpha$ value for Copper Sulphate is 0.01 and the maximum acceptable concentration value, taken from the value of sulphates, $\mathrm{SO}_{4}$, is $1000 \mathrm{mg} \mathrm{L}^{-1}$, that means $0.015 \mathrm{~kg} \mathrm{~m}^{-3}$. The calculation for Copper Sulphate is therefore:

$$
((0.01 \times 3) /(1)) / \text { annual production }=W F_{\text {proc,grey }}
$$

\subsection{Total Water Footprint}

The highest total water footprint values were observed in 2007, 2012, 2014 and 2016, while the lower values were observed in 2013, 2015 and 2017 (Figure 1). The largest component was Green Water while the smallest component was Blue Water. The green component is not directly controlled by the manager and little can be done to reduce green water. However, the grey and blue components (already small in our case) can be reduced with more sustainable agronomic practices.

\section{Discussion}

The main objective of this paper was to calculate the WF related to the production of $1 \mathrm{~kg}$ of olives in a rainfed olive orchard managed through low environmental impact techniques. The water footprint indicator of the total amount of consumptive water changes through time depending on the geography, mainly due to meteorological conditions and olive orchard evapotranspiration [7]. Unlike other more general indicators, such as the ecological footprint, WF gives a detailed illustration of human appropriation of natural water resources, allowing for more efficient water management policies [20].

WF results from this study are lower than results reported for rainfed traditional growing systems in Apulia [9] and consequently less impactful on the water cycle. The Total WF value in this case study is less than half the value in Apulia and the world average value (Table 3 and Figure 2).

\begin{tabular}{|c|c|c|c|c|c|c|c|c|}
\hline \multicolumn{3}{|c|}{ N.1-Sterpeto, Assisi (PG), Italy, 2019} & \multicolumn{3}{|c|}{ N.2-Apulia Region, Italy [9] } & \multicolumn{3}{|c|}{ N.3-[5] } \\
\hline BLUE WF & 0.001 & 0.084 & BLUE WF & 0.822 & 23.951 & BLUE WF & 0.512 & 16.819 \\
\hline GREY WF & 0.164 & 13.793 & GREY WF & 0.410 & 11.940 & GREY WF & 0.060 & 1.971 \\
\hline
\end{tabular}

Table 3. WF average values comparison between this case study, Apulia and standard world value.

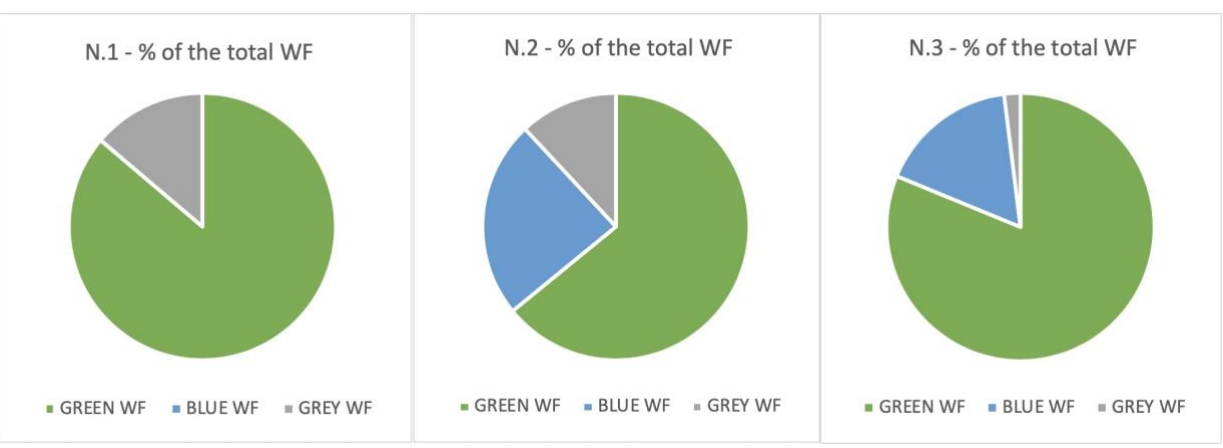

Figure 2. WF types percentages of the total WF in the three compared studies; N.1: Sterpeto, Assisi (PG), Italy, 2019; N.2: Apulia region, Italy [9]; N.3: WaterFootprintNetwork, 2019. 
The lower value of Umbria Green WF, compared to the Apulia grove, is probably due to the higher level of annual precipitation $(820 \mathrm{~mm})$ and the higher production of olives in $\mathrm{kg} \mathrm{ha}^{-1}(6197)$. Apulia has an annual precipitation of $560 \mathrm{~mm}$ with a lower average production of olives in $\mathrm{kg} \mathrm{ha}^{-1}$ (2500). In general, good availability of water is not related to high production of olives. For example, in 2014, high precipitation (1153 $\mathrm{mm}$ year ${ }^{-1}$ ), especially in July, favored olive flies attacks that resulted in a very low production of olives and increased total water footprint. On the contrary, in 2015, despite the low precipitation $\left(642 \mathrm{~mm}_{\text {year }}{ }^{-1}\right)$, a high production of olives decreased the total water footprint. Moreover, for Green Water, Dichio et al. [10] pointed out the fundamental role of cover crops rather than tilled soil in the store of water reserves.

The blue WF, which represents almost $24 \%$ of total WF in Apulia, is related only with the amount of water used in the ammonium nitrate production $\left(822.1 \mathrm{~m}^{3} \mathrm{t}^{-1}\right.$ year $\left.{ }^{-1}\right)$. In particular, the amount of water to produce $1 \mathrm{~kg}$ of ammonium nitrate is equal to $4.671 \mathrm{~m}^{3} \mathrm{~kg}^{-1}$ [9]. In the present case study, the blue WF is attributed only to the water used in the urea production $\left(16 \mathrm{~m}^{3} \mathrm{t}^{-1}\right.$ year $\left.{ }^{-1}\right)$ and represents $0.94 \%$ of total WF. This low value is due to the amount of water used to produce $1 \mathrm{~kg}$ of urea, which is equal to $0.0234 \mathrm{~m}^{3} \mathrm{~kg}^{-1}$. This result indicates that urea fertilizer, compared to ammonium nitrate, results in a more sustainable form of agriculture from an environmental point of view.

The large gap in grey WF values between the present study $\left(0.16 \mathrm{~m}^{3}\right.$ of water $\mathrm{kg}^{-1}$ of olives similar to the value found by Pellegrini [9], $\left.0.410 \mathrm{~m}^{3} \mathrm{~kg}^{-1}\right)$ and the WaterFootprintNetwork $\left(0.06 \mathrm{~m}^{3} \mathrm{~kg}^{-1}\right)$, is likely due to the different parameters adopted abroad relative to parameters fixed by Italian law. Thus, study values are most comparable to other Italian studies. In another study conducted in Umbria Region [13], which also considered the transformation phase, values equaled $1418 \mathrm{~m}^{3} \mathrm{t}^{-1}$ for the Green water, $1245 \mathrm{~m}^{3} \mathrm{t}^{-1}$ for the Blue water and $1500 \mathrm{~m}^{3} \mathrm{t}^{-1}$ for the Grey Water.

\section{Conclusions}

In the present case study, WF of traditional low environmental impact techniques used in managed rainfed olive orchard were analyzed. The Green water component was the highest $\left(1024 \mathrm{~m}^{3} \mathrm{~kg}^{-1}\right)$, followed by grey $\left(0.164 \mathrm{~m}^{3} \mathrm{~kg}^{-1}\right)$ and blue water $\left(0.001 \mathrm{~m}^{3} \mathrm{~kg}^{-1}\right)$.

The blue water varied largely due to the water requirement of fertilizer production. Ammonium nitrate production requires forty times more water than urea production. Farmers can utilize different productive management activities (e.g., using urea instead of ammonium nitrate) to reduce the blue water component. "Low input" olive growing has good environmental performance in terms of a low water footprint and a low carbon footprint $[15,21,22]$. The water footprint, in particular the blue and grey water components, could be a useful tool for olive growers to measure their environmental performance and enhance sustainable agronomic practices.

Agriculture requires substantial amounts of water and water scarcity is a contemporary problem [23]. Thanks to WF assessment tools, a clearer perspective of crop water usage was obtained. High olives production and the low anthropic water input in this case study work properly to optimize the tightly interconnected food, energy and water resource systems.

Supplementary Materials: The following are available online at http://www.mdpi.com/2077-0472/10/1/8/s1. Table S1: Climatic data of rainfall, minimum and maximum temperatures, relative humidity, wind speed and solar radiation from 2007 to 2017.

Author Contributions: Conceptualization, L.R., L.R. and P.P.; methodology, L.R., L.R., R.C. and P.P., software, L.R. and L.R.; validation, P.P.; formal analysis, L.R. and L.R.; investigation, L.R., L.R., A.B., F.D., P.S. and S.R.; resources, P.P.; data curation, L.R., L.R., P.S. and S.R.; writing - original draft preparation, L.R., L.R. and P.P.; writing-review and editing, L.R., L.R. and P.P.; visualization, L.R., L.R. and P.P.; supervision, P.P.; project administration, P.P.; funding acquisition, P.P. All authors have read and agreed to the published version of the manuscript.

Funding: This research was partially funded by the EU project LIFE OLIVE4CLIMATE (LIFE15 CCM/IT/000141).

Acknowledgments: We are grateful to David J. Nowak Senior Scientist/i-Tree Team Leader Forest Service Forest Inventory and Analysis-5 Moon Library, SUNY-ESF, Syracuse, NY 13210 for the linguistic revision of the manuscript.

Conflicts of Interest: The authors declare no conflict of interest. 


\section{References}

1. IPCC. Summary for Policymakers. In Climate Change 2013: The Physical Science Basis. Contribution of Working Group I to the Fifth Assessment Report of the Intergovernmental Panel on Climate Change; Stocker, T.F., Qin, D., Plattner, G.K., Tignor, M., Allen, S.K., Boschung, J., Nauels, A., Xia, Y., Bex, V., Midgley, P.M., Eds.; Cambridge University Press: Cambridge, UK, 2013; p. 15.

2. Hoekstra, A.Y.; Hung, P.Q. Virtual Water Trade: A Quantification of Virtual Water Flows between Nations in Relation to International Crop Trade; Value of Water Research Report Series No. 11; UNESCO-IHE: Delft, The Netherlands, 2002; pp. 1-116.

3. Hoekstra, A.Y.; Chapagain, A.K.; van Oel, P.R. Advancing water footprint assessment research: Challenges in monitoring progress towards sustainable development goal 6. Water 2017, 9, 438. [CrossRef]

4. Gerbens-Leenes, P.W.; Mekonnen, M.M.; Hoekstra, A.Y. The Water Footprint of poultry, pork and beef: A comparative study in different countries and production systems. Water Res. Ind. 2013, 1-2, 25-36. [CrossRef]

5. Water Footprint Network. Available online: http://waterfootprint.org/en/resources/interactive-tools/productgallery/ (accessed on 1 February 2019).

6. Hoekstra, A.Y.; Chapagain, A.K.; Aldaya, M.M.; Mekonnen, M.M. The Water Footprint Assessment Manual: Setting the Global Standard; Publisher Earthscan: London, UK, 2011; pp. 3-15, 22-32, 38, 40-42, 46, 52, 56.

7. Lamastra, L.; Suciu, N.A.; Novelli, E.; Trevisan, M. A new approach to assessing the water footprint of wine: An Italian case study. Sci. Total Environ. 2014, 490, 748-756. [CrossRef] [PubMed]

8. FAOSTAT. Available online: http://faostat3.fao.org/compare/E (accessed on 15 January 2019).

9. Pellegrini, G.; Ingrao, C.; Camposeo, S.; Tricase, C.; Contò, F.; Huisingh, D. Application of Water Footprint to olive growing systems in the Apulia region: A comparative assessment. J. Clean Prod. 2015, 112, 2407-2418. [CrossRef]

10. Dichio, B.; Palese, A.M.; Montanaro, G.; Xylogiannis, E.; Sofo, A. A preliminary assessment of Water Footprint components in a Mediterranean olive grove. Acta Hortic. 2014, 1038, 671-676. [CrossRef]

11. Mota, M.; Nogueira, A.M.; Guimarães, A.; Gonzales, L.F.; Paço, T.A.; Correia, M.M.; Coelho, R.; Vaz, M.; Santos, F.L.; Alegre, A.H.; et al. Impact of Irrigation in Production and Oil Properties in Intensive and Hedgerow Olive Groves. Acta Hortic. 2014, 1038, 553-558. [CrossRef]

12. Paço, T.A.; Nogueira, A.M.; Silvestre, J.C.; Gonzales, L.F.; Santos, F.L.; Pereira, L.S. Water Requirements and Footprint of a Super-intensive Olive Grove under Mediterranean Climate. In Geophysical Research Abstract; EGU2012-11301; General Assembly: Vienna, Austria, 2012; Volume 14.

13. Rocchi, L.; Paolotti, L.; Boggia, A. Sustainability and typical products. The case of the Water Footprint of "PDO Umbria" olive oil. In Sustainability of the Agri-Food System: Strategies and Performances, Proceedings of the 50th SIDEA Conference, Lecce, Italy, 26-28 September 2013; De Gennaro, B.C., Nardone, G., Eds.; Universitas Studiorum S.r.l.: Mantova, Italy, 2014; Volume 165, pp. 170-171.

14. Notarnicola, B.; Salomone, B.; Petti, R.; Renzulli, P.A.; Cerutti, A.K. Life Cycle Assessment in the Agri-food Sector, Case Studies, Methodological Issues and Best Practices; Springer: Berlin, Germany, 2015; pp. 29-30.

15. Proietti, S.; Sdringola, P.; Desideri, U.; Zepparelli, F.; Brunori, A.; Ilarioni, L.; Nasini, L.; Regni, L.; Proietti, P. Carbon footprint of an olive tree grove. Appl. Energy 2014, 127, 117-118. [CrossRef]

16. Badruzzaman, M.; Oppenheimer, J.; Hess, T.; Smith, H.; Upson, S.; Postle, M.; Jacngelo, J.G. Water Footprints: A News Concept for Sustainable Water Utilities; Water Research Foundation: Denver, CO, USA, 2014; pp. 6-10.

17. IPCC (Intergovernmental Panel on Climate Change). Guidelines for National Greenhouse Gas Inventories; IPCC: Geneva, Switzerland, 2006; Volume 3, p. 8.

18. Franke, N.A.; Boyacioglu, H.; Hoekstra, A.Y. Grey Water Footprint Accounting: Tier 1 Supporting Guidelines; Values of Water Research Report Series No. 65; UNESCO-IHE: Delft, The Netherlands, 2013; pp. 17-19.

19. Decreto Legislativo 3 Aprile 2006, n. 152. Norme in Materia Ambientale. Supplemento Ordinario Alla “Gazzetta Ufficiale della Repubblica Italiana". 2006. Available online: http://extwprlegs1.fao.org/docs/pdf/ ita64213.pdf (accessed on 27 December 2019).

20. Amicarelli, V.; Lagioia, G.; Gallucci, T. The Water Footprint as an indicator for managing water resources: The case of the Italian olive oil. Int. J. Sustain. Econ. 2011, 3, 434-436. [CrossRef] 
21. Proietti, S.; Sdringola, P.; Regni, L.; Evangelisti, N.; Brunori, A.; Ilarioni, L.; Nasini, L.; Proietti, P. Extra Virgin Olive oil as carbon negative product: Experimental analysis and validation of results. J. Clean Prod. 2017, 166, 550-562. [CrossRef]

22. Proietti, P.; Sdringola, P.; Brunori, A.; Ilarioni, L.; Nasini, L.; Regni, L.; Pelleri, F.; Desideri, U.; Proietti, S. Assessment of carbon balance in intensive and extensive tree cultivation systems for oak, olive, poplar and walnut plantation. J. Clean Prod. 2016, 112, 2613-2624. [CrossRef]

23. Schull, V.Z.; Daher, B.T.; Gitau, M.W.; Mehan, S.; Flanagan, D.C. Analyzing FEW Nexus Modeling Tools for Water Resources Decision-Making and Management Applications. Food Bioprod. Process. 2020, 119, 108-124. [CrossRef]

(C) 2019 by the authors. Licensee MDPI, Basel, Switzerland. This article is an open access article distributed under the terms and conditions of the Creative Commons Attribution (CC BY) license (http://creativecommons.org/licenses/by/4.0/). 